\title{
KEBANGKITAN PENGGUNAAN CANDI DI BANYUWANGI
}

\author{
Poniman \\ Universitas Hindu Negeri I Gusti Bagus Sugriwa Denpasar \\ Email: poniman@uhnsugriwa.ac.id
}

\begin{abstract}
The existence of Hindus in the archipelago was mostly centered on Java at first. This can be seen historical evidence in the form of a temple that is still remaining. However, actually the temple is a continuation of the sacred buildings in the previous civilization. There was a change in the treatment of the temple at that time because the worshipers had changed their understanding as a result of the new theological understanding he was introducing. Humans in carrying out religious traditions coupled with their level of intelligence, they will always reduce what exists and will create new civilizations to free them from the confinement of previous traditions. Likewise, the reappearance of the use of temples as part of Hindu religious life in Banyuwangi, which he had long abandoned as a means of rituals as a sign of revival. So it raises problems that need to be researched related to "What is the Basis for the Resurrection of the Use of Temples in Banyuwangi". The theory used in this research includes; Talcot Parsons' Structural Functional, Van Genneb's of Life Needs, Symbolic Interactionism, Theory of Religion. The methods used in qualitative research on the revival of the use of temples for the Hindi people in Banyuwangi include; In-depth Interviews, Participatory Observations, Documents, visual materials and data tracing published online.This study has the following results, including the basis for the revival of the use of temples: 1) There is a relationship between community systems, 2) the influence of reciprocal systems, 3) social integration, 4) social systems, 5) cultural revival, 6) agreement Together, 7) Historical Journeys.
\end{abstract}

\section{Keyword: Temple; Awakening}

\begin{abstract}
Abstrak
Keberadaan umat Hindu di Nusantara ini banyak berpusat di tanah Jawa pada mulanya. Hal ini bisa terlihat bukti-bukti sejarah berupa Candi yang masih tersisa. Namun demikian sesungguhnya Candi merupakan kelanjutan dari bangunan suci pada peradaban sebelumnya. Adanya perubahan terhadap perlakuan terhadap Candi dimasa itu diakibatkan para pemujanya sudah beralih paham akibat adanya paham teologi baru yang diperkenalkannya. Manusia dalam menjalankan tradisi keagamaan yang dibarengi oleh tingkat kecerdasannya, mereka akan selalu mereduksi apa yang ada dan akan menciptakan peradaban baru guna membebaskan mereka dari kungkungan tradisi sebelumnya. Demikian juga munculnya Kembali Penggunaan Candi sebagai bagian dari kehidupan keagamaan Hindu di Banyuwangi yang sudah lama ditinggalkannya untuk sarana ritualnya sebagai pertanda kebangkitan kembali. Sehingga menimbulkan permasalahan yang perlu diteliti terkait "Apa yang menjadi Dasar Kebangkitan Penggunaan Candi di Banyuwangi”. Teori yang digunakan dalam penelitian ini; Fungsional Struktural dari Talcot Parsons, Kebutuhan Hidup dari Van Genneb, Interaksionisme Simbolik, Teori Religi. Metode yang digunakan dalam penelitian kualitatif tentang kebangkitan penggunaan candi bagi Umat Hindi di Banyuwangi diantaranya; Wawancara Mendalam,
\end{abstract}


Observasi Partisipasi, Dokumen, bahan visual dan penelusuran data yang dimuat secara online. Penelitian ini memiliki hasil yang dapat di paparkan sebagai berikut diantaranya Dasar Kebangkitan Penggunaan Candi: 1) Adanya Hubungan antara Sistem Masyarakat, 2) Pengaruh Sistem Timbal-Balik, 3) Integrasi Sosial, 4) Sistem Sosial, 5) Revivalisasi Budaya, 6) Kesepakatan Bersama, 7) Perjalanan Sejarah.

\section{Kata Kunci: Candi; Kebangkitan}

\section{PENDAHULUAN}

Perkembangan Hindu di Indonesia pada zaman pemerintahan Repulik ini terus mengalami perubahan. Namun demikian umat Hindu selain menjalankan aktivitasnya untuk selalu melaksanakan bhakti sesuai dengan konsep sraddha, maka memiliki suatu tuntutan untuk melunasi tiga hutang yang dinamakan Tri Rna yaitu hutang pada Dewa yang telah menciptakan, hutang pada leluhur yang telah melahirkan dan hutang pada guru yang telah memberikan ilmu pengetahuan. Selain berkwajiban melunasi hutang atas Tri Rna, penganut Hindu juga memiliki tugas untuk tetap menjaga moralitas. Hal ini juga sejalan pendapat dari Haviland bahwa agama memiliki fungsi sosial diantaranya mampu memberikan sanksi sejumlah besar tata kelakuan dan disamping itu sebagai fungsi psikologis terhadap kelakuan moralitas dan sebagai pemelihara solidaritas (Haviland, 2004, pp. 214-215). Untuk menjaga solidaritas itulah penganut Hindu memiliki tata kelola keagamaannya dengan konsep sraddha dan kerangka agamanya.

Konsep yang menjadi dasar keimanan Hindu terdiri dari lima konsep yang dikenal dengan Panca Sraddha. Kelima Sraddha itu diantaranya; 1) sraddha tentang adanya Brahman, 2) sraddha tentang adanya Atman, 3) sraddha tentang adanya Hukum Karma (hukum sebabakibat), 4) sraddha tentang adanya Samsara (punarbhava) dan 5) sraddha tentang adanya Moksa (pembebasan akhir) (Maswinara, 2002, pp. 53-54). Setelah menjalankan sikap sraddha tersebut, maka dalam menjalankan tata keagamaannya disusun tiga kerangka yang dikenal Tri (tiga) Kerangka (konsep/rangka) Dasar (pondasi) Agama Hindu. Ketiga kerangka dasar itu diantaranya; Tattwa, Susila dan Acara (Adiputra, 2009, p. 25).

Pelunasan hutang Tri Rna merupakan bagian dari Acara kegamaan yang salahsatunya melalui ritual. Dalam menjalankan ritual keagamaan, senatyasa dibalut dengan budaya. Demikian juga pada ritual kematian sangat kental dengan budaya yang ada. Penggunaan berbagai budaya pada berbagai ritual termasuk pada ritual kematian bagi umat Hindu sangat penting, mengingat keberadaan budaya dikatakan sebagai bagian bagi kehidupan manusia itu sendiri, secara menyeluruh budaya meliputi; pandangan ideologi, pandangan filosofi, adanya sistem nilai, kesatuan norma, etika yang berlaku, estetika yang diciptakan, juga adanya candi, keberadaan seni lukis serta seni tari bahasa, juga adanya bangunan serta aneka sistem symbol demikian juga keberadaan gambelan, folklore serta kearifan local lainnya, yang secara bentuk nyata dinamik meliputi adanya sikap hidup maupun gaya hidup, dan tatacara hidup dimisalkan adanya budaya disiplin maupun budaya kerja serta budaya instan dan lain-lain. Dipandang perlu mengadopsi budaya yang ada sebagai wahana dalam pengembangan suatu Agama, maka Hindu sangat dekat dengan keberadaan budaya itu. Hal ini dipandang penting akibat keberadaan manusia itu merupakan objek utama dalam suatu Agama yang dalam hal ini memiliki budaya dalam pelaksanaannya (Triguna, 2008, p. 33). Sebagai objek utama dalam budaya, manusia senatyasa berkarya untuk terus memajukan budaya bahkan melakukan perubahan atas budaya yang ada demi kelangsungan hidupnya. Demikian juga adaya perubahan dalam pelaksanaan ritual juga dipengaruhi oleh tingkat kemajuan ilmu pengetahuan bagi umat penganut agama. Menurut Walker bahwa orang bisa berpendapat adanya perubahan evolusioner tidaklah bersifat historis (Walker, 2010, p. 99). Namun sesungguhnya perubahan secara evolusioner juga ada yang bersifat karena pengaruh historis. 
Dalam menjalankan tradisi keagamaan yang dibarengi oleh tingkat kecerdasannya, mereka akan selalu mereduksi apa yang ada dan akan menciptakan peradaban baru guna membebaskan mereka dari kungkungan tradisi sebelumnya. Menurut Sutrisno dan Putranto, bahwa keruntuhan atas peradaban manusia akan terjadi apabila manusia gagal dalam memunculkan berbagai kreativitas didalam menghadapi berbagai tantangan. Demikian keruntuhan akan memuncak apabila terdapat ketidaksesuaian atas peradaban manusia dengan kesatuan sosial berantakan dan adanya ketiakberdayaan atas keberadaan kebudayaan itu memberi dalam memberikan tanggapan untuk bersifat kreatif dalam menghadapi berbagai tantangan pada setiap zaman. Dari pendapat tersebut, sungguh suatu kemunduran jika umat Hindu tidak memiliki kepekaan dan kreatifitas didalam menghadapi perkembangan jaman (Sutrisno, Mudji dan Putranto, 2009, p. 70).

Umat Hindu sebagai penganut Agama di Nusantara ini mengalami pasang surut. Keberadaan umat Hindu di Nusantara ini banyak berpusat di tanah Jawa pada mulanya. Hal ini bisa terlihat bukti-bukti sejarah berupa Candi yang masih tersisa. Namun demikian sesungguhnya Candi merupakan kelanjutan dari bangunan suci pada peradaban sebelumnya. Bahwa sebelum dikenalnya suatu Agama, maka di Nusantara sudah dikenal system penguburan mayat seperti ditemukannya Menhir (lambang peringatan moyang) Dolmen (tempat sajian nenek moyang), sarcophagus/keranda (tempat menimpan mayat), kubur batu (peti mayat) juga adanya punden berundak-undak yaitu tempat pemujaan (Soekmono, 2017, pp. 72-73).

Peningkatan tradisi pada masyarakat suku Jawa terjadi Ketika masa masuknya paham Hindu. Dimulai peningkatannya dari Kutai Kalimantan yang terjadi sekitar tahun 400 M, selanjutnya masuk ke Pulau Jawa yaitu pada masa berdirinya Kerajaan Tarumanagara yang berada diwilayah Jawa Barat pada sekitar 400-500 M, diteruskan perkembangannya sampai ke wilayah Jawa Timur, yang selanjutnya terjadilah puncak kejayaaanya dengan berdirinya kerajaan Majapahit yaitu sekitar tahun 1293-1528 Masehi. Pengaruh perkembangan Hindu pada tahun 1429-1522 M mengalami masa kelam. Hal itu akibat pengaruh Hindu ditanah Jawa akibat kejayaan Majapahit sudah mengalami suatu fase kemunduran yang diakibatkan oleh berbagai hal (Soekmono, 2017, pp. 38-78).

Berdasarkan pendapat itu, bahwa peradaban Hindu pernah mengalami keruntuhan dimasa lampau akibat berbagai hal diantaranya adanya pengaruh baru yang masuk meruntuhkan kerajaan dimasa itu yang didominasi oleh paham Hindu. Hal itu dijelaskan dalam cerita adanya pengaruh Puteri Islam dari Cempa (Putri Cina) yang dijadikan permaisuri Raja Majapahit kala itu, Majapahit sangat toleran pada Islam kala itu, maka menjelang abad ke 15 runtuhlah peradaban Hindu yang ditandai masuknya paham Islam menguasai tanah Jawa (Soekmono, 2015, pp. 44-46). Dengan runtuhnya kerajaan Majapahit, maka runtuh pula ideologinya, hal ini diakibatkan adanya Ideologi baru yang dibangun oleh penguasa yang baru.

Ketika masa kerajaan Hindu sedang tumbuh, maka banyak berdiri berbagai Candi yang megah sebagai symbol kekuasaan dan kejayaan suatu kerajaan. Salah satu peninggalan Candi Hindu terbesar hingga saat ini masih megah terdapat di Jawa Tengah yaitu Candi Prambanan. Dalam candi Prambanan terdapat prasasti Śivagrha yang menunjukkan angka 11 pada suklapaksa yaitu bulan Margasira pada tahun 778 Saka bahwa angka tersebut menunjukkan tanggal 12 Nopember 856 Masehi (Ratni, 2020). Demikian juga hingga ke wilayah Jawa Timur banyak dijumpai Candi Hindu yang masih tersisa seperti Candi Jawi, Candi Penatara, Candi Muara Tikus dan sebagainya. Namun keberadaannya sebagai caga budaya dan bukan lagi menjadi tempat ritual bagi umat Hindu yang kini sudah bangkit Kembali.

Saat kebangkitannya Kembali umat Hindu di masa Republik ini, salah satunya kebangkitan Hindu di Banyuwangi, maka berbagai bentuk Candi sudah dibangun di berbagai pura maupun tempat tersendiri di berbagai wilayah Banyuwangi. Mereka terlihat bersemangat kembali melihat tradisi ritual pemujaan Leluhur yang biasa mereka lakukan mendapatkan perhatian khusus. Namun demikian dari keberadaan Candi itu banyak yang tidak memahami tentang makna dan fungsinya, bahkan masih banyak juga pura yang belum memiliki Candi. 
Berbagai varian ini mengundang perhatian peneliti untuk meneliti secara mendalam terkait dengan tradisi Penggunaan Candi tersebut sehingga menarik minat peneliti untuk melakukan penelitian dengan tema yaitu "Kebangkitan Penggunaan Candi di Banyuwangi" sekaligus menjadi judul dalam penelitian ini. Adapun yang menjadi permasalahan yang akan diteliti terkait "Apa yang menjadi dasar kebangkitan penggunaan Candi Bagi Umat Hindu di Banyuwangi"

\section{METODE}

Mengingat jenis penelitiannya adalah kualitatif, maka metode yang digunakan juga suatu metode kualitatif. Dalam pendekatan kualitatif, tidak diperlukan suatu angka-angka maupun grafik serta statistik, tetapi lebih menekankan pada makna dari suatu peristiwa atau fenomena yang didapat dari informan. Demikian juga dalam hal memakai suatu metode observasi pada saat pengumpulan data merupakan suatu upaya yang terbaik untuk jenis pendekatan penelitian kualitatif (Bungin, 2015, pp. 51-52). Demikian juga pada penelitian tentang Kebangkitan Penggunaan Candi di Banyuwangi, peneliti mempergunakan pendekatan kualitatif, sehingga peneliti nantinya tidak mempergunakan angka-angka, statistik maupun grafik dalam pengambilan data maupun penyelesaian hasil analisis data, akan tetapi lebih mengedepankan makna atas simbol-simbol, kejadian, prilaku masyarakat penelitian, seni dan budaya, serta prilaku individu penganut Hindu pada objek penelitian, sehingga data yang didapat setelah dianalisis dipahami secara mendalam.

Untuk mengumpulkan suatu data pada jenis penelitian yang berjenis kualitatif ini, maka secara umum dapat dilaksanakan dengan media fieldwork, hal itu dapat dijelaskan sebagai suatu langkah atau kegiatan yang dapat dipedomani dengan mendengarkan, mengamati, merasakan, mencatat, menyatukan serta merangkum berbagai fenomena data dan informasi tentang berbagai kasus sehingga dapat diselidiki keberadaannya (Salim, 2001, p. 99). Hal tersebut juga ditegaskan menurut Lofland, bahwa suatu sumber data utama dalam penelitian kualitatif merupakan kata-kata, kemudian tindakan, yang selebihnya adalah data tambahan seperti dokumen dan lain sebagainya (dalam Moleong 1993: 112).

Hal ini dapat diartikan bahwa penelitian yang bersifat kualitatif dapat bekerja pada aturan yang bersifat alami serta berupaya untuk memahami, memberi tafsiran, terhadap fenomena yang dilihat serta arti yang diberikan oleh informan kepada peneliti (Moleong, 1993, p. 4). Demikian juga menurut Salim Hadisutomo, bahwa sumber data penelitian kualitatif dapat bersifat alamiah dengan maksud bahwa peneliti harus berusaha memahami gejala nyata secara langsung dalam kehidupan di masyarakat sehari-hari dalam hal ini pada tempat penelitian (dalam Sudikan, 2001, pp. 85-86). Oleh karena itu penelitian terkait Kebangkitan Penggunaan Candi Bagi di Banyuwangi maka dalam mendapatkan data yang akurat, peneliti melakukan pendalaman data dalam waktu yang cukup lama. Hal itu dilakukan oleh peneliti sebagai upaya agar data yang didapat memiliki akurasi yang maksimal, oleh karena itu peneliti berupaya agar sering datang kelokasi penelitian serta sedapatnya dapat menyatu dengan keberadaan objek yang diteliti.

Melalui beberapa kali melakukan pengamatan ketika peneliti berada dilokasi penelitian, maka keberadaan data yang terdapat dalam penelitian hasil dari observasi maupun wawancara dapat dipisahkan menjadi dua macam data. Adapun kedua data yang diperlukan dalam penelitian tentang kebangkitan penggunaan Candi diantaranya sebagai jenis data utama atau Data Primer serta data pendukung atau Data Skunder. Teknik pengumpulan data; Wawancara secara mendalam, Observasi peranserta atau Partisipasi, dokumen, bahan visual dan penelusuran data yang ada di media internet. Hal itu sejalan dengan pemikiran dari Bungin, bahwa dalam pengumpulan data pada jenis penelitian kualitatif yang memiliki independen terhadap semua metode pengumpulan data serta teknik analisis data adalah pengumpulan data melalui metode wawancara mendalam, bahan dokumen, observasi partisipan, bahan visual, dan penelusuran data melalui internet (Bungin, 2017, p. 110). Adapun Instrumen Penelitian yang 
Utama adalah peneliti sendiri. Kemudian didukung oleh berbagai fasilitas, seperti keuangan, transportasi, Laptop, kamera handphone, Paket Data internet dan sebagainya. Hasil penelitian akan disajikan dalam bentuk deskriftif, namun demikian peneliti juga memakai teori yang dapat membantu dalam mendeskripsikan hasil penelitian sehingga dapat dideskripsikan menjadi laporan akhir penelitian. Adapun teori yang dipakai pada penelitian ini; Teori Fungsional Struktural dari Talcot Parsons, Teori Kebutuhan Hidup dari Van Genneb, Teori Interaksionisme Simbolik serta Teori Religi.

\section{HASIL DAN PEMBAHASAN}

Kebaradaan Candi yang sudah dibangun di Banyuwangi hingga saat ini terus mengalami perubahan. Sampai saat peneliti melaksanakan penelitian sudah ditemukan beberapa kebangkitan Candi yang terbangun diantaranya sebagai berikut:

1. Candi Agung Waseso: Di Desa Karangdoro Kecamatan Tegalsari

2. Candi Merak Marga Mukti: Di Dusun Senepo Desa Barurejo Kecamatan Siliragung

3. Candi Penataran Sabdho Utomo: Di Desa Barurejo Kecamatan Siliragung

4. Candi Tumpang Pitu: Di Desa Pesanggaran Kecamatan Pesanggaran

5. Candi Tirta Purwa Bhuwana: Di Desa Pesanggaran Kecamatan Pesanggaran

6. Candi Topeng Reges: Di Desa Sumberagung Kecamatan Pesanggaran

7. Candi Nirmala Jati: Di Desa Sumberagung Kecamatan Pesanggaran

8. Candi Brahma Selosanti: Di Desa Pesanggaran Kecamatan Pesanggaran

9. Candi Dwijati Sasana: Di Desa Buluagung Kecamatan Siliragung

10. Candi Purwo: Di Desa Kedungasri Kecamatan Tegaldlimo

11. Candi Anom Purwo Kencono: Di Desa Kedungasri Kecamatan Tegaldlimo

12. Candi Luhur Moksajati: Di Desa Kumendung Kabupaten Banyuwangi

13. Candi Luhur Blambangan: Di Desa Wonoasih Kecamatan Glenmore

14. Candi Gumuk Kancil: Di Desa Wonoasih Kecamatan Glenmore

Keberadaan Candi-Candi tersebut diatas merupakan bangunan baru yang dibangun atas semangat dan partisipasi umat Hindu. Dengan demikian keberadaannya terus memerlukan perhatian bagi pemimpinnya agar lestari. Adapun yang menjadi dasar Kebangkitan Penggunaan Candi di Banyuwangi dalam hal ini yang dilakukan oleh Penganut Hindu yang erat kaitannya dengan ritual pemujaan pada leluhurnya, maka berdasarkan hasil penelitian baik melalui Observasi, Wawancara, Dokumentasi dan penelusuran data yang terdapat di media online, maka dapat dipaparkan hasilnya sebagai berikut;

\section{Terjadinya Hubungan antara Sistem Masyarakat}

Keberadaan Umat Hindu di Banyuwangi pada dasarnya tidak terlepas dari pengaruh tokoh dari Bali. Hal ini mengingat bangkitnya Hindu di daerah ini akibat peran dari Pedande Kemenuh pada tahun 1967. Bahwa sebelumnya masyarakat di Banyuwangi terutama Umat Hindu didaerah penelitian mereka masih menganut sistem Kejawen. Dalam perkembanganya mereka mengadakan perkumpulan-perkumpulan yang didalamnya membabarkan keilmuan tentang Kejawen.

Demikian semakin hari semakin berkembang sehingga mereka secara sukarela pada tahun 1967 memeluk Agama Hindu. Dalam perkembangannya keberadaan Umat Hindu disini masih tetap menggunakan Tradisi Kejawen. Hal itu dapat dilihat ketika mepraktikkan tatacara keagamaannya diantaranya dengan menghaturkan sesaji Kenduri pada saat-saat tertentu. Demikian dalam ritual kematian mereka masih memakai perhitungan selamatan mulai geblak atau saat sehari kematian, kemudian pitungdino (7) hari, petangpuluhandiino (40) hari, nyatusandino 100 hari, pendak pisan atau setahun, pendakpindo atau 2 tahun dan pendaktelu atau 3 tahun yang selanjutnya dinamakan Nyewu atau yang ke seribu hari dan setelah itu Ngijing. Menurut pengamatan peneliti bahwa terdapat suatu sistim kepercayaan yang utuh yang mereka masih memiliki sebagai orang kejawen, hal tersebut dapat dilihat dalam tindakan 
ketika hendak melakukan ritual. Sebelum melakukan ritual, maka mereka terlebih dahulu mencari perhitungan hari yang pas untuk pelaksanaan sesuai tradisinya. Umat Hindu di Banyuwangi masih mempercayai perhitungan adanya hari baik-buruk. Misalnya dalam pelaksanaan ritual kematian bagi salah satu keluarganya yang sudah meninggal, maka mereka memakai perhitungan kapan datangnya ritual ke 7 hari pitungdinoan, ritual yang ke 40 hari atau petangpuluhdinoan, dan seterusnya hingga ritual Nyewu. Perhitungan atas hari itu merupakan tradisi yang mereka dapatkan dari pendahulunya dan sudah menjadi tradisi yang tidak dapat ditinggalkan.

Apabila diamati, prilaku Umat Hindu di Banyuwangi dalam menjalankan tradisi kepercayaannya terkait ritual pada kematian, menunjukkan mereka mewarisi sistim kepercayaan sebagai orang Kejawen. Mereka menggabungkan antara sistim agama dengan sistim kepercayaan yang sesungguhnya memiliki perbedaan dalam sumber ajarannya. Menurut James W. Fowler yang merupakan seorang Profesor Teologi dari New York bahwa Ia membedakan Iman dan Agama seperti kutipan berikut ini;

Pertama, Ia memandang bahwa agama dikatakan sebagai sebuah tradisi yang bersifat kumulatif, terdiri dari berbagai bentuk kumpulan ungkapan keyakinan yang dapat diteruskan para generasi terdahulu di masa lampau. Yang termasuk tradisi dapat berbentuk teks, kitab suci maupun berbagai prosuk hukum, juga ujaran maupun berbagai mitos yang berkembang. Demikian juga tradisi ramalan serta berbagai kisah pewahyuan. Adanya beraneka macam symbol serta berbagai macam tradisi lainnya seperti seni tari, seni music, seni isan, moralitas, pandangan teologi, berbagai macam kepercayaan demikian juga ritus, arsitektur, serta liturgy, serta lainnya. Selanjutnya yang kedua yaitu, Ia berpandangan bahwa keberadaan Iman memiliki perbedaan dengan keberadaan kepercayaan. Dikatakan baha kepercayaan merupakan bentuk pemilikan atau pemelukan terhadap ide-ide tertentu yang diyakini. Dalam hal masalah agama, kemunculan pada ide-ide tersebut merupakan bentuk usaha dari manusia dalam upaya mengekspresikan berbagai pengalaman dan relasinya terhadap keberadaan yang transenden ke dalam wujud berbagai konsep atau berbagai pengertian serta proposisi maupun dalil-dalil yang ada. Suatu kepercayaan bisa dapat dikatakan bentuk ekpresi dari iman atau keyakinan. Sedangkan Iman merupakan ekpresi manusia dalam kepasrahan atau berserahdiri dalam upaya memperoleh atau memaknai atas berbagai keadaan ataupun kondisi dirinya. Dijelaskan tentang Iman merupakan upaya kita untuk mengerti serta pandangan atas berbagai situasi hidup kita serta kaitannya dengan adanya gambaran yang minim serta lebih bersifat suatu kesadaran terhadap situasi akhir nanti. Demikian juga Iman dapat dikatakan sebagai dimensi sosial atau relasional yang memiliki corak tiga serangkai atau triadik, hal itu dapat meliputi adanya kepercayaan serta kesetiaan kita untuk orang lain pada komunitas kita saat ini serta terhadap berbagai pusat atas hasil suatu nilai, adanya suatu kekuasaan akhir yang memiliki kebersamaan yang dipedomani (Fowler, 1995, pp. 7-8).

Melihat pandangan Fowler diatas dikaitkan dengan prilaku masyarakat Hindu di Banyuwangi, maka mereka juga memiliki kemiripan, bahwa dalam kesehariannya mereka begitu taat pada petuah-petuah orang tua, mitos-mitos juga mereka berlaku baik bukan karena memiliki kedalaman ilmu agama dengan membaca Kitab Suci, melainkan kebanyakan atas petunjuk dari orang yang melahirkan serta tradisi sosial yang tergambar dalam praktik.

Ajaran Kejawen yang sangat umum dilakukan dalam ritualnya adalah kenduri atau Wilujengan. Setiap ada permasalahan ritual maka wilujengan atau Kenduri tidak bisa ketinggalan. Hal ini menunjukan bahwa didalam masyarakat Jawa sudah terdapat nilai-nilai. Mereka tidak berani meninggalkan tradisi Kenduri atau Wilujengan karena itu sudah menjadi tradisi dan komitmennya sebagai orang Jawa. Mereka ada ketakutan tersendiri jika dalam suatu acara ritual tidak diadakan Kenduri. Secara kompak mereka akan setuju jika diajak kenduri 
sebelum kegiatan baik dalam ritual keagamaan terlebih ritual kematian. Konsep kenduri bukan barang yang asing, melainkan sudah menjadikannya bagian dari kehidupan orang Jawa. Hal ini jika dikaitkan dengan pandangan Parson tentang ritual bahwa, suatu aktivitas ritual seperti kenduri dalam sistim masyarakat Kejawen merupakan bagian dari mekanisme control. Lebih lanjut Parson mengatakan bahwa "Mekanisme sosial sebagai sarana dalam menanamkan model budaya, seperti adanya beraneka nilai yang ada, keberadaan bahasa, dan sebagainya. Melalui proses tersebut maka masyarakat bisa memperoleh serta memiliki komitmen atas berbagai norma yang sudah ada. Sedangkan media kontrolnya juga berupa sistim sosial, sehingga perbedaan-perbedaan dapat diminimalkan. Adapun yang menjadi mekanisme control menurut Parson antara lain; a) sanksi-sanksi b), pelembagaan, c) aktivitas ritual, d) penyelamatan pada keadaan yang kritis dan tidak normal, e) pengintegrasian kembali supaya terdapat keseimbangan yang bisa dicapai berikutnya, dan f) pelembagaan kekuasan dalam upaya melaksanakan tatanan sosial" (Wirawan, 2014, p. 47).

Apabila konsep Candi yang digunakan dalam rangkaian Ritual Kematian, maka hal itu bukan sesuatu yang asing bagi masyarakat kejawen bahwa pada jaman kerajaan Hindu mereka juga mengenal adanya Candi. Beberapa situs Candi diberbagai tempat di Jawa menjadi bukti dan saksi bahwa mereka memiliki sistim sosial yang dilandasi tradisi-tradisi pendahulunya.

Gejala-gejala inilah yang menjadi cikal bakal untuk kembali mengikuti ajaran Jawa, sehingga sampai saat ini jika terdapat pemahaman konsep baru yang terkait dengan tradisi Jawa, maka mereka secara kompak menerimanya termasuk ketika Konsep Candi ditawarkan guna meluhurkan leluhurnya ketingkat yang lebih tinggi. Hal ini jika diamati dengan pandangan Cohen maka terdapat kesesuaian, bahwa dalam konsesusnya Cohen memilki 9 konsep yaitu; 1) adanya norma dan nilai-nilai yang berlaku dimasyarakat. Keberadaan orma maupun nilai dikatakan sebagai elemen dasar bagi kehidupan social masyarakat. 2) Komitmen merupakan bentuk Konsekwensi atas kehidupan sosial masyarakat, 3) keadaan kepastian atas kekompakan masyarakat, 4) adanya ketergantungan Kehidupan sosial pada pada solidaritas masyarakatnya, 5) Didasari Kerjasama serta saling memperhatikan sebagai hal yang diperlukan bagi kehidupan social, 6) keberadaan suatu Sistem sosial dapat memiliki ketergantungan pada consensus, 7) adanya pengakuan oleh masyarakat atas keberadaan otoritas yang memiliki keabsahan, 8) adanya suatu sistim sosial yang memiliki sifat integrative, 9) adanya suatu sistim sosial yang memiliki kebertahanan (Wirawan, 2014, p. 45).

Keberadaan Umat Hindu yang mendiami suatu wilayah dengan hidup berdampingan penganut keyakinan lainnya, mereka mampu bertahan dan bangkit atas dasar keyakinannya yang ditanamkan oleh tokoh pendahulunya. Mereka mengakui adanya otoritas yang absah, sehingga tidak berani melawan arus. Oleh karenanya sistim awalnya secara tersembunyi. Namun mereka memiliki sistim keyakinan tersendiri terkait budaya dan tradisi terlebih dalam hal pandangan Ketuhanan, pandangan pada ritual kematian, ritual proses hidup, maka berdasarkan pandangan dari Talcot Parson maupun Cohen diatas, mereka mampu bertahan dan eksis sampai saat ini, sehingga mereka lagi-lagi mampu membangkitkan sistim ritual memakai Candi guna melanjutkan tradisi pendahulunya. Kebangkitan itu dilandasi solidaritas yang tinggi, bahkan antar sesama warga yang memiliki perbedaan agamapun mereka memiliki solidaritas, karena mereka merasa memiliki persamaan identitas sebagai orang Jawa yang luhur budhiya atau baik prilakunya.

Mereka juga merupakan bagian dari sistim sosial yang ada di masyarakat yang mendiami wilayah Desa di seluruh wilayah Banyuwangi, maka mereka juga bertahan ditengah-tengah perbedaan itu. Hal itu dapat diamati oleh peneliti berdasarkan data bahwa selain dari pengaruh tersebut juga adanya hubungan dengan sistim masyarakat yang ada disekitar Banyuwangi. Bahwa didaerah Banyuwangi terdapat kelompok masyarakat yang heterogen. 


\section{Adanya Pengaruh Sistem Timbal-Balik}

Akibat pengaruh dari tokoh Bali tempo dulu dan sampai saat ini juga sering didatangi para rohaniawan Hindu dari Bali, maka terjadilah hubungan saling mempengaruhi diantara dua arah. Dalam hal ini yang dimaksud hubungan tersbut bahwa ketika terdapat budaya dilingkungan Banyuwangi yang masih eksis dan relevan, maka hal itu menjadi modal dasar untuk dipertahankan dan hingga saat ini masih lestari terkait tradisi dalam prosesi Kematian itu. Namun sebaliknya ketika dilokasi penelitian masyarakatnya ingin menyerap ilmu yang diperlukan guna meningkatkan Sraddha sesuai Ajaran Hindu yang dipeluknya, maka kehadiran Tokoh Rohaniawan Hindu sangat diperlukan seperti yang terjadi hingga saat ini, bahwa mereka sering berinteraksi dengan para Pandhita baik yang ada di Jawa maupun yang didatangkan dari Bali guna menambah wawasan keagamaannya.

Bersamaan dengan itulah memunculkan pemahaman lama yang terpendam yang selama ini sudah tidak dilakukan, maka konsep penggunaan Candi seperti yang pernah dilakukan oleh leluhur Jawa pada Zaman Kerajaan Hindu kini terbangun kembali. Hal ini dilakukan guna peningkatan prosesi ritual terkait Kematian yang selama ini masih selesai ditingkat penguburan, maka setelah terjadi interaksi Timbal-Balik ini dilanjutkanlah dengan tingkatan ritual melinggihkan Leluhurnya yang disthanakan di Candi. Dengan prosesi ini mereka tidak lagi merasa khawatir atas keadaan Kijing diareal Pemakaman Umum yang terkadang dirusak atau hilang akibat ulah manusia lainnya.

Berdasarkan pemaparan diatas, maka jika dikaitkan dengan pendapat Parson, hal itu terdapat adanya saling keterkaitan antara satu dengan lainnya. Masyarakat dikatakan sebagai sistim sosial yang didalamnya terdapat berbagai bagian atau unsur yang saling memerlukan dan saling menyatu dalam mencapai keseimbangan. Perubahan yang terjadi pada suatu bagiantertentu dapat membawa pula pada bagian yang lainnya (Ritzer, George dan Goodman, 2010, p. 25)(Ritzer, 1992: 25). Demikian juga ketika terjadi perubahan dalam penggunaan Candi, maka terjadi pula perubahan prilaku dalam Ritual. Hal itu terlihat jika sebelumnya mereka selesai dengan Ritual Nyewu, maka mereka akan melanjutkan lagi pada ritual Mestanakan leluhurnya di pelinggih Candi. Jika sebelumnya mereka melakukan ritual kematian selesai di kuburan umum, maka setelah memiliki Candi dilanjutkanlah prosesi Ritualnya menuju Candi sehingga keberadaan Kijing tidak lagi menjadi istimewa. Melalui terbentuknya Candi sebagai sutu konsep atas kesepakatan bersama menjadi milik khusus Umat Hindu maka hal itu berdampak pada ketenangan batin yang tak terhingga karena derajat leluhurnya memiliki tempat yang lebih istimewa. Dengan demikian terjadi suatu sistim timbalbalik atas perubahan yang terjadi, baik pada posisi leluhurnya yang lebih meningkat dibandingkan sebelumnya, juga adanya ketenangan batin akibat tidak ada rasa khawatir dibanding dengan berakhir di areal pekuburan.

\section{Integrasi Sosial}

Pengaruh hubungan timbal-balik diatas mempengaruhi juga Integrasi Sosial sebagai dasar bangkitnya penggunaan Candi. Integrasi Sosial itu terjadi tidak tanpa sebab, melainkan ada pendahuluannya. Didahului oleh sebab banyaknya Kijingan atau bangunan Makam yang rusak dan hilang atau dirusak sengaja dihilangkan orang lain, sementara keluarga penerusnya masih hidup. Selanjutnya didatangkanlah tokoh-tokoh penting yang memahami ajaran Agama dan Budaya Hindu.

Ketika diadakanlah diskusi-diskusi maka terjadilah kesepakatan untuk menggunakan Candi sebagai Sthana Leluhur mereka secara bersama-sama. Demikian paparkan bahwa hal itu menjadi dasar peningkatan pemahaman mengingat pengetahuan keagamaan mereka terbatas, maka kehadiran tokoh sangat penting. Umat Hindu Banyuwangi sangat senang dan tidak terjadi permasalahan, justru yang ada semakin bersemangat karena memiliki Candi sebagai tempat yang aman untuk menstanakan Leluhurnya. 
Adanya pengaruh Integrasi Sosial seperti diatas sejalan dengan pendapat Parsons bahwa sebuah sistim harus mengatur dan membentuk komponennya terhubung satu dengan lainnya sehingga masing-masing komponen memliki fungsi yang penting (Ritzer, George dan Goodman, 2010, p. 121). Demikian juga dipertegas lagi oleh Nasikun bahwa seandainya keberadaan integrasi sosial yang ada tidak dapat tercapai secara sempurna, tetapi secara mendasar bahwa sistem sosial akan mengalami perkebangan terus dengan demikian apabila menghadapi adanya perubahan-perubahan dimungkinkan ada hingga pada derajat yang minimal (Nasikun, 2012, pp. 13-14). Oleh karena itu Integrasi Sosial menjadi dasar dari kebangkitan penggunaan Candi di Kabupaten Banyuwangi.

\section{Sistem Sosial}

Keberadaan Umat Hindu di Banyuwangi tidak terlepas dari lingkungan masyarakat lainnya. Mereka hidup secara bersama-sama dalam suatu kawasan yang heterogen. Walaupun mereka berbeda keyakinan namun mereka rukun tanpa terjadi konflik antar agama dan keyakinan itu. Namun demikian mereka memiliki suatu sistim-sistem tertentu yang menjadi pembeda antara umat Hindu dan Umat lainnya. Akibatnya antara sistim itu terjadi saling pandang. Jika pada umat lainnya dalam Sistemnya secara terorganisir mereka secara rutin melakukan perkumpulan keagamaan baik dirumah maupun ditempat ibadahnya, maka bagi Umat Hindu juga demikian.

Akibat pengaruh Sistem Sosial itulah yang membangkitkan untuk saling memamerkan kebaikannya. Sehingga antar sistim terjadi persaingan dalam hal tata keagamaan. Akibat persaingan itu mereka saling menonjolkan nilai-nilai positifnya bahkan saling mengunjungi antar umat ketika terjadi tradisi-tradisi ritual terutama ritual kematiannya. Rasa gengsi itu menimbulkan semangat Positif guna membangunAgamanya, oleh karena itu timbulnya ide-ide perbaikan tata keagamaan bagi Umat Hindu sangat dipengaruhi Sistem Sosial itu. Dengan demikian terbangunnya Candi dilingkungan Pura dengan nuansa seni penuh keindahan dapat menjadi Nilai tersendiri dalam upaya persaingan antar sistim kearah yang lebih baik.

Sejalan dengan hal diatas, maka Parsons mengatakan bahwa Sistem Sosial diharuskan memperlengkapi atas kebutuhan sosial lainnya demikian juga diharapkan mampu memelihara, memperbaiki, memberi motivasi-motivasi baik secara pribadi maupun melalui berbagai kultural sehingga dapat menciptakan serta dapat mendorong terhadap rangsangan yang diberikan (Ritzer, George dan Goodman, 2010, p. 121). Dengan demikian sangat penting peran dari pengaruh sistim Sosial atas terjadinya kebangkitan penggunaan Candi Bagi Umat Hindu di Kabupaten Banyuwangi.

\section{Revivalisasi Budaya}

Pemahaman atas Bahasa Revivalisme perlu diketahui yang bermakna penghidupan atau kebangkitan Kembali ataupun dapat diartikan kebangkitan Kembali sesuai pendapat Peter Salim sedangkan revivalisme kontenporer dapat dipahami sebagai keberlanjutan atas revivalisme pada waktu yang lampau menurut Azra (Murkilim, 2017). Demikian dalam hal ini terkait kebangkitan penggunaan Candi bahwa timbulnya suatu gerakan yang berupaya membangun kembali bentuk seni bangunan Candi yang pernah terjadi pada masa kerajaan Hindu untuk masa kini merupakan bentuk revivalisasi budaya. Jika pada masa itu Candi diperuntukkan khusus keluarga Raja, maka masa kini diperuntukkan bagi semua Umat Hindu, agar mereka menjadi leluasa dan memiliki kebanggaan atas rasa mempunyai Candi tanpa adanya intimidasi oleh penguasa seperti pada jaman itu, sehingga membangun bangunan megah untuk leluhurnya bukan hanya untuk golongan elit, namun semua sama rata seperti hakikatnya manusia semua sama-sama memiliki badan dan Roh, maka mereka berhak mendapatkan perlakukan yang sama guna menemukan jalan menuju Tuhannya. Hal itu sebagai bentuk guna mempertahankan keberadaan tradisi yang selama ini mereka yakini. 
Terbangunnya kembali Candi yang terdapat di Utama Mandala Pura sesungguhnya suatu sikap kerinduan atas relief dan motif atau still Candi yang menjadi tradisi para raja-raja pada jaman kerajaan. Hal itu mengingatkan kembali cerita terkait Cinandi yang dilakukan pada jaman kerajaan terhadap Raja mereka yang meninggal. Seperi dikutip dari kisah yang tertuang pada Serat Pararaton maka telah terjadi suatu tradisi untuk mengupacarai atau Selamatan terhadap Roh Leluhurnya yang dinamakan Upacara Sradha Agung yang terjadi pada tahun 1284. Demikian jika seorang Raja yang meninggal, Roh mereka di Candikan (chinandi ring). Maka berdasarkan keberadaan dari teks Pararaton tersebut bahwa Revivalisme Budaya telah terjadi di Banyuwangi, hanya saja tidak untuk mencandikan Atma dari para raja, namun diperuntukkan kepada seluruh Atma dari umat Hindu yang ada disekitar Pura yang telah menjalani proses Ritual penyucian. Oleh karena itu jelas bahwa keinginan kembali membangun Candi seperti jaman kerajaan muncul namun dengan berbagai perubahan yang disesuaikan dengan kebutuhan saat ini yang terjadi pada kebangkitan penggunaan Candi Bagi Umat Hindu di Kabupaten Banyuwangi.

\section{Kesepakatan Bersama}

Proses perubahan pemakaian Candi bukanlah serta-merta, melainkan akibat kesepakatan antar umat Hindu yang didalamnya juga terdapat para pemimpin umatnya. Dengan demikian mereka sepakat walaupun sebagian juga belum paham pada mulanya, namun bersamaan dengan waktu mereka memahami bahwa keberadaan Candi itu memang sangat diperlukan. Hal itu juga sesuai dengan pendapat Parson bahwa yang menjadi dasar adanya perubahan sosial terdapat tiga macam yaitu adanya penyesuaian yang mungkin dilakukan oleh sistem sosial itu sendiri untuk mengantisipasi adanya perubahan yang datang dari luar kemudian adanya deferensiasi struktural dan fungsional yang tumbuh melalui berbagai proses, serta adanya anggota masyarakat yang memiliki penemuan baru (Nasikun, 2012, pp. 13-14). Maka dari itu keberadaan Candi dianggap sebagai kemajuan yang dirindukan. Dirindukan demikian, akibat Candi sesungguhnya sebagai tradisi lama para raja-raja, namun ketika mereka memakai Candi untuk leluhur mereka, maka ada kebanggaan tersendiri bagi peningkatan Budaya sehingga kesepakatan yang dicapai itu sebagai bentuk keluhuran Budi karena sudah mengagungkan Leluhurnya.

\section{Perjalanan Sejarah}

Sejalan dengan hal keruntuhan Majapahit bahwa menurut Bawa Atmaja, bahwa kejayaan Majapahit terjadi pada abad ke-14, kemudian Majapahit mengalami kemundurannya pada abad ke-16 yang selanjutnya terjadilah konversi agama secara besar yang diakibatkan dengan berbagai metode logika mereka tawarkan sehingga gelombang konversi tidak dapat dibendung (Atmadja, 2017). Pengaruh kekuasaan Majapahit runtuh terdapat berbagai kemungkinan kaum candela, mleca, tuca (Rahardjo, 2007) serta kaum sudra yang cerdas melakukan penyebabnya diantaranya akibat Majapahit masih menerapkan Sistem Kasta, yang sangat Dominan sehingga golongan yang diharamkan melakukan protes yang memunculkan gelombang kekerasan hingga kacaulah sistim kerajaan yang besar saat itu tiada mampu mengatur rakyatnya (Nadwi, 1987). Ditambah lagi ketika Bangsa Penjajah masuk kewilayah Nusantara termasuk Jawa pada tahun 1595 (Ricklefs, 1994).

Wilayah Banyuwangi yang semula merupakan satu kesatuan kerajaan dibawah pengaruh Bali sekitar 150 tahun lamanya, maka ketika Blambangan mengalami keruntuhan akibat serangan dari prajurit Mataram tahun1636-1640, dibawah kekuasaan Sultan Agung. Maka pada tahun 1639 Blambangan yang selalu didukung bala bantuan dari prajurit Bali, jatuh ke kekuasaan Mataram (Ricklefs, 1994), namun Mataram tidak mampu mengislamkan Blambangan sepenuhnya akibat keturunan Prabhu Tawangalun masih kukuh memeluk agama Hindu sampai tahun 1690 (Sudjana, 2001, p. 29). 
Mereka yang menjadi penghuni di Kabupaten Banyuwangi ini merupakan campuran antara penduduk asli pada masa Blambangan juga yang datang dari wilayah Blitar, Malang, Kediri, Jawa Tengah yang mana mereka sekitar tahun 1924 mereka berdatangan ke Blambangan. Dengan demikian mereka sangat dekat sekali nalurinya dengan keberadaan bangunan Candi-Candi yang hingga saat ini masih tersisa sebagai warisan sejarah nasional.

Penganut Hindu yang mewarisi tradisi leluhurnya maka keberadaan Nenek Moyangnya yang menjadi pendahulu dalam menginspirasi penggunaan Candi. Hal ini diakibatkan sesungguhnya mereka adalah para penghuni yang dahulunya keturunan dari kerajaan Blambangan yang hingga saat ini masih terdapat Situs Candi di Alas Purwo dan di Ompak Songgo Blambangan serta mereka yang datang dari berbagai daerah Jawa terutama dari daerah Kediri, Malang, Blitar dan juga dari Jawa Tengah. Mereka adalah keturunan masyarakat Jawa jaman Majapahit. Pernyataan ini disampaikan mereka bahwa ketika menjadi Hindu maka mereka dapat selalu mengenang dan melestarikan seni budaya pendahulunya dengan tetap memegang teguh Ajaran kepribadian Jawa bahwa keberadaan Leluhur disebut sebagai Gusti Katon atau perwujudan Tuhan bagi sang anak. Oleh karena itu melakukan pemujaan kepada Leluhur adalah keutamaan.

Sebagai pewaris tradisi nenek moyangnya yang memiliki ajaran Kejawen, maka mereka dapat selalu berprilaku luhur, menghormati orang tuanya sampai akhir hidupnya bahkan meproses kematiannya dengan ritual yang mereka jalankan. Dalam tradisinya mereka menghormati leluhurnya sampai membuat bangunan Kijing pada arela pemakaman. Sejalan dengan hal diatas Van Genneb menjelaskan bahwa ketika seseorang meninggal sesungguhnya sedang mengalami masa peralihan. Peralihan dari kehidupan badan dan sosial, menuju kehidupan yang baru yaitu dalam hal ini alam Roh suci, maka dari itu diperlukan kebutuhan hidup juga untuk kehidupan Roh. Sehingga keberadaan kehidupan Roh memiliki rasa Aman karena selalu diperhatikan oleh keluarganya yang masih berbadan (Koentjaraningrat, 2014).

\section{SIMPULAN}

Adanya hutang yang perlu dilunasi oleh umat Hindu terutama kepada leluhurnya, maka umat Hindu senantyasa merawat orang tuanya dari hidup sampai meninggal yang sudah menjadi tradisi. Dalam perkembangannya mengalami perubahan yang semula cukup sampai pada penguburan dan pembuata kijing, maka munculah kebangkitan membangun Candi bagi leluhurnya maupun bagi tokoh yang telah berjuang pada masa dahulu dalam kehidupan umat Hindu di Banyuwangi. Dasar Kebangkitan Penggunaan Candi: 1) Adanya Hubungan antara Sistem Masyarakat, 2) Pengaruh Sistem Timbal-Balik, 3) Integrasi Sosial, 4) Sistem Sosial, 5) Revivalisasi Budaya, 6) Kesepakatan Bersama, 7) Perjalanan Sejarah.

\section{DAFTAR PUSTAKA}

Adiputra, G. R. (2009). Pengetahuan Dasar Agama Hindu. IPEBI - BANK INDONESIA. Atmadja, N. B. (2017). Geneologi Keruntuhan Majapahit. Yogyakarta: Pustaka Pelajar. Bungin, B. (2015). Metodologi Penelitian Kualitatif. Jakarta: PT Raja Grafindo.

Bungin, B. (2017). Penelitian Kualitatif, Komunikasi, Ekonomi, Kebijakan Publik dan Ilmu Sosial. Jakarta: Kencana.

Fowler, J. W. (1995). Teori Perkembangan Kepercayaan. Yogyakarta: Kanisius.

Haviland, W. A. (2004). Antropologi (Soekadijo (ed.)). Jakarta: Erlangga.

Koentjaraningrat. (2014). Sejarah Teori Antropologi 1. Jakarta: Universitas Indonesia Press. Maswinara, I. W. (2002). Konsep Panca Sraddha. Surabaya: PT Paramita.

Moleong, L. . (1993). Metodologi Penelitian Kualitatif. Bandung: PT Remaja Rosdakarya.

Murkilim. (2017). New Revivalisme Islam. NUANSA, 10, 2. https://doi.org/http://dx.doi.org/10.29300/nuansa.v10i2.651

Nadwi, A. H. . (1987). Islam dan Dunia. Badung: Angkasa.

Nasikun. (2012). System Sosial Indonesia. Jakarta: PT Raja Grafindo. 
Rahardjo, S. (2007). Kota-Kota Prakolonial Indonesia, Pertumbuhan dan Keruntuhan. Jakarta: Fakultas Ilmu Pengetahuan Budaya Universitas Indonesia.

Ratni, N. P. (2020). Fungsi dan Keistimewaan Makna Candi Prambanan Bagi Umat Hindu di Idonesia. Penelitian Agama Hindu, $4, \quad 4$. http://jayapanguspress.penerbit.org/index.php/JPAH

Ricklefs, M. . (1994). Sejarah Indonesia Modern. Yogyakarta: Universitas Gajah Mada.

Ritzer, George dan Goodman, D. J. (2010). Teori Sosiologi Modern. Jakarta: Kencana.

Salim, A. (2001). Teori dan Paradigma Penelitian Sosial (dari Denzim Guba dan Penerapannya). Yogyakarta: PT Tiara Wacana.

Soekmono. (2015). Pengantar Sejarah Kebudayaan Indonesia 1 (30th ed.). Yogyakarta: Kanisius.

Soekmono. (2017). Candi Fungsi dan Pengertiannya (1st ed.). Yogyakarta: Ombak.

Sudikan, S. Y. (2001). Metode Penelitian Kebudayaan. Surabaya: Citra Wacana.

Sudjana, I. M. (2001). Nagari Tawon Madu. Yogyakarta: Larasan.

Sutrisno, Mudji dan Putranto, H. (2009). Teori-Teori Kebudayaan. Yogyakarta: Kanisius.

Triguna, I. B. G. Y. (2008). Estetika Hindu dan Pembangunan Bali. Denpasar: PT. Mabhakti.

Walker, J. A. (2010). Desain, Sejarah, Budaya Sebuah Pengantar Komprehensif. Jakarta: Jalasutra.

Wirawan, I. . (2014). Teori-Teori Sosial Dalam Tiga Paradigma-Fakta Sosial, Definisi Sosial, \& Perilaku Sosial. Jakarta: Kencana Prenada Media Group. 